\title{
Composition of spontaneous black garlic fermentation in a water bath
}

\author{
Fitri SETIYONINGRUM ${ }^{1 *}$ (D), Gunawan PRIADI ${ }^{1}$, Fifi AFIATI ${ }^{1}$, Nina HERLINA ${ }^{1}$, Akhmad SOLIKHIN ${ }^{1}$
}

\begin{abstract}
Garlic was fermented spontaneously in a water bath with a temperature of $72{ }^{\circ} \mathrm{C}$ and relative humidity close to $90 \%$. The fermentation periods were 0 (fresh garlic), 7, 14, and 21 days. Several physicochemical properties: antioxidant capacity, total polyphenol, flavonoid content, $\mathrm{pH}$, and browning intensity were determined. All of the chemical properties of black garlic increased significantly during the fermentation, except the $\mathrm{pH}$ value. The $\mathrm{pH}$ value was decreased conveniently during the time of fermentation. Browning intensity as physical properties also increased during the fermentation. A volatile compound in garlic during the fermentation process was analyzed by SPME-GCMS and was quite different compared with fresh garlic. A water bath could be considered as fermentation instrument of black garlic processes.
\end{abstract}

Keywords: black garlic; volatile compounds; SPME-GCMS.

Practica Application: Production of black garlic by spontaneous fermentation in a water bath and its composition.

\section{Introduction}

Garlic has been used as a seasoning food in Asian and medical herb due to its potential benefits i.e. antimicrobial, antioxidant, antitumor and immunomodulatory activities (Banerjee et al., 2013; Sultan et al., 2014). However, its consumption is still limited because the taste, flavor, and odor aren't preferred (Tanamai et al., 2017; Ngan et al., 2017), it has a tendency to cause stomach upset and it might be toxic at high doses (Bae et al., 2012). Black garlic is a garlic product that is produced to be preferred and it easily consumed. Black garlic produced by heating garlic at high temperature and high humidity (Ngan et al., 2017; Kang et al., 2008; Bae et al., 2014; Choi et al., 2014; Kimura et al., 2017), enzyme treatment and curing (Wang and Sun, 2017). Black garlic is also defined as a fermented product, made by spontaneous fermentation of whole garlic bulbs (Kim et al., 2012; Lee et al., 2011; Sato et al, 2006). The term spontaneous fermentation of black garlic supported by Qiu et al. (2018) has been succeeded isolating of 4 microbe genera: Thermus, Corynebacterium, Streptococcus, and Brevundimonas from black garlic procesed in the heating oven at $80^{\circ} \mathrm{C}$ for 12 days on vacuum sealed bags. On the other hand, Setiyoningrum et al. (2018) made black garlic through (unspontaneous) fermentation, inoculated with Saccharomyces kluyveri Y97. In this research, black garlic was made focus by spontaneous fermentation in a water bath.

There were increasing properties in black garlic compared with fresh garlic such as S-allyl cysteine (SAC) that increased 5 to 6 times (Bae et al., 2012; Wang et al., 2012), extended shelf-life (Chu et al., 2007), higher phenolic content 5-8 times (Kim et al., 2012), lower off- flavor (Kimura et al., 2017) and lower fructan content (Yuan et al., 2016). Black garlic has a sweeter taste (Ngan et al., 2017) caused by increases in glucose, fructose, and sucrose content (Zhang et al., 2015), as well as sticky and jelly-like texture (Bae et al., 2014). The previous study on producing black garlic with heating was carried out by Kim et al. (2012); Bae et al. (2014); Zhang et al. (2015); Zhang et al. (2016); Ngan et al. (2017); Wang and Sun (2017); and Lu et al. (2018). The thermal process leads to non-enzymatic browning reactions such as the Maillard reaction, caramelization and chemical oxidation of phenol (Bae et al., 2014) associated with increased antioxidant properties Several tools used to produce black garlic with the heating method, are, among others, oven drying (Ngan et al., 2017; Bae et al., 2012), heat and humidity box (Wang \& Sun, 2017), chamber, humidity control room (Yuan et al., 2018) and thermohygrostatic chamber (Choi et al., 2014; Lu et al., 2018). A water bath is a thermostatic instrument widely used for incubating samples at a constant temperature over a long period of time in a water media. A water bath has control of temperature and high humidity. The aims of this study were to process black garlic with a water bath and characterization of its properties.

\section{Materials and methods}

\subsection{Materials}

Fresh garlic (Allium sativum L.) was obtained from the local market in Bogor, Indonesia. The reagents used in this research were methanol, aluminium (III) chloride (Ajax Finechem NSW, Australia), 1,1- diphenyl-2-picrylhydrazyl (Sigma-Aldrich Chemical Co. (St. Louis, MO, USA), Follin-ciocalteu, ethanol potassium acetate and sodium carbonate (Merck,VWR International, Spain), ultrapure water (Generik Jakarta, Indonesia). 


\subsection{Methods}

Sample preparation and extraction of black garlic

The unpeeled fresh garlic was fermented spontaneously in a water bath with a temperature of $72^{\circ} \mathrm{C}$ and relative humidity closed to $90 \%$. Sampling was made at different times for 7, 14, and 21 days. The extraction method in this research was described by Kim et al. (2012) with some modification. Measurement of $\mathrm{pH}$ and browning intensity Browning intensity and $\mathrm{pH}$ were determined in each sample during the fermentation process. Garlic browning intensity was determined by Yuan et al. (2018). The determination was obtained in duplicate.

\section{Measurement of functional properties}

The functional properties measured in this research were total polyphenol, flavonoid content and DPPH radical scavenging activity. Total polyphenol was determined using the Folin-Ciocalteu method by Chang et al. (2002) with some modification. In a $1.5 \mathrm{~mL}$ Eppendorf tube, $0.05 \mathrm{~mL}$ extract garlic was mixed with $0.8 \mathrm{~mL}$ distilled water, $0.05 \mathrm{~mL}$ of $10 \%(\mathrm{v} / \mathrm{v})$ Folin-Ciocalteu, and $0.1 \mathrm{~mL}$ of $7 \%(\mathrm{v} / \mathrm{v})$ sodium carbonate. The mixture was incubated at room temperature for 30 mins. The absorbance was read at $750 \mathrm{~nm}$ and total phenolics was calculated from a calibration curve, using gallic acid as standard. Total flavonoid was determined by the method of Chang et al. (2002) with minor modification (2002). To $0.05 \mathrm{~mL}$ extract garlic, $0.05 \mathrm{~mL}$ of $10 \%$ $(\mathrm{w} / \mathrm{v}) \mathrm{AlCl}_{3}$ water solution, $0.05 \mathrm{~mL}$ of $1 \mathrm{M}$ potassium acetate, $0.3 \mathrm{~mL}$ ethanol absolute, and $0.6 \mathrm{~mL}$ distilled water were added. After 30 mins incubation, the absorbance was read at $415 \mathrm{~nm}$. The total flavonoid was calculated as quercetin from the calibration curve. For DPPH activity, $0.8 \mathrm{~mL}$ of DPPH methanolic solution was mixed with $0.2 \mathrm{~mL}$ of the garlic extract. The mixture was incubated at room temperature with darkroom condition for 30 mins. The absorbance was read at $517 \mathrm{~nm}$ and the radical scavenging activity was calculated as follows, radical scavenging activity $(\%)=(\mathrm{P}-\mathrm{Q}) / \mathrm{P} \times 100 \%, \mathrm{P}$ : absorbance of blank, and Q: absorbance of the sample. This method follows Muanda et al. (2011) with minor modifications.

\section{Volatile compound by SPME-GCMS}

Chemical compounds as volatile form either in fresh garlic or black garlic were analyzed by SPME-GCMS as described by Molina-Calle et al. (2017) with a slight modification, two replicates. The absorption of volatile compounds in samples was performed at $60^{\circ} \mathrm{C}$ for $40 \mathrm{mins}$ by the SPME tool. Volatile compounds were trapped in the fiber of SPME was analyzed using an Agilent Technologies 7890A-5975 c inert XLEI/CI gas chromatograph (Agilent Technologies Co., USA) equipped with a mass spectra detector (MS) and fitted with an HP-5MS capillary column (length $30 \mathrm{~m}, 0.25 \mathrm{~mm}$ i.d, $0.25 \mu \mathrm{m}$ film thickness). The 2, 4, 6 trimethylpyridine of $1 \%$ (Sigma Aldrich) was used as internal standard $(20 \mu \mathrm{L} /$ samples $)$. The fiber of SPME was injected into GC-MS using split 1:5 and helium as a carrier gas. The injector temperature was $180^{\circ} \mathrm{C}$ and the detector temperature was $280^{\circ} \mathrm{C}$. The oven temperature program was set as follows: initially at $40^{\circ} \mathrm{C}$, and held for $5 \mathrm{mins}$, increased $10^{\circ} \mathrm{C} / \mathrm{min}$ to $250{ }^{\circ} \mathrm{C}$, and held for 5 mins. The cut solvent time was set at 2 mins. LRI (Linear
Retention Index) was determined by comparing the retention time of all constituents of the samples with the retention time of homologous series of n-alkanes $\left(\mathrm{C}_{6}-\mathrm{C}_{2} 6\right)$ (Sigma - Aldrich Pte Lvtd, Singapore) on the same column and condition above.

\section{Statistical analysis}

Data were subjected by a one-way analysis of variance (ANOVA, $\mathrm{p}=0.05$ ) using SPPS software (SPSS, Chicago, II, USA). Differences in samples were determined by the Duncan test.

\section{Result and discussion}

\subsection{The pH and browning intensity}

The decrease in $\mathrm{pH}$ value during the black garlic process shown in Table 1. Comparing fresh garlic (FG), the $\mathrm{pH}$ value of black garlic with all treatments did decline significantly $(\mathrm{p}<0.05)$. The same phenomenon has been described by Toledano-Medina et al. (2016) and Bae et al. (2014). The decrease in $\mathrm{pH}$ value on black garlic due to the increasing total acid content (Choi et al., 2014). Liang et al. (2015) reported that the concentration of acetic acid was gradually increased during the processing of garlic, degradation result of hexose during processing. Research by Choi et al. (2014) described that the total acidity of garlic has increased from $0.40 \mathrm{mg} / \mathrm{kg}$ to $2.60 \mathrm{mg} / \mathrm{kg}$ after 21 days of heating. During the fermentation process, acetic acid was formed and its concentration increased gradually (Table 2 ).

Browning intensity of black garlic increased during fermentation process significantly (Table 1.), due to the formation of several compounds resulting from Maillard browning. In the initial stages of the Maillard reaction, colorless intermediate products are produced due to the amine-sugar condensation process and Amadori rearrangement. At the intermediate stage, there are several reactions such as dehydration of sugar, fragmentation of sugar, and degradation of amino acids (degradation of Strecker) leading toan increased browning. In the final stage of the Maillard reaction, occurs the aldol condensation process, aldehyde-amine condensation, and formation of heterocyclic nitro compounds occur leading to a further increase of browning intensity (Choi et al., 2014; Billaud et al., 2004). The higher concentration of MRPs induced the higher browning intensity produced. Billaud et al. (2004) noticed that the formation of MRPs (Maillard Reaction the intensity Product) is initiated from the reaction between glucose and cysteine and is influenced by temperature and processing time.

Table 1. pH value and browning intensity of garlic during the fermentation process in a water bath.

\begin{tabular}{llc}
\hline Treatment & $\mathrm{pH}$ & Browning Intensity \\
\hline FGB & $6.06^{\mathrm{a}}$ & $0.013^{\mathrm{a}}$ \\
BG7D & $4.94^{\mathrm{b}}$ & $0.742^{\mathrm{b}}$ \\
BG14D & $4.31^{\mathrm{c}}$ & $0.973^{\mathrm{c}}$ \\
BG21D & $3.47^{\mathrm{d}}$ & $2.685^{\mathrm{d}}$ \\
\hline
\end{tabular}

FGB: fresh garlic; BG7D: black garlic fermented for 7 days; BG14D: black garlic fermented for 14 days; BG21D: black garlic fermented for 21 days. Different superscript letters in the same column indicate significantly different means among samples according to Duncan test at $\mathrm{P}<0.05$ 
Setiyoningrum et al.

Table 2. Changes of functional properties of garlic fermented spontaneously in a water bath.

\begin{tabular}{lccc}
\hline Treatment & $\begin{array}{c}\text { Total polyphenol } \\
\text { (mg QE/kg dry basis) }\end{array}$ & $\begin{array}{c}\text { Flavanoid content } \\
(\text { mg GAE/kg dry basis) }\end{array}$ & $\begin{array}{c}\text { Antioxidant activity } \\
(\% \text { inhibition of 0.2mM DPPH }\end{array}$ \\
\hline FGB & $89468.55^{\mathrm{a}}$ & $2348.65^{\mathrm{a}}$ & $21.67^{\mathrm{a}}$ \\
BG7D & $101328.71^{\mathrm{b}}$ & $3825.51^{\mathrm{a}}$ & $26.03^{\mathrm{b}}$ \\
BG14D & $132510.22^{\mathrm{c}}$ & $16255.38^{\mathrm{b}}$ & $89.1^{\mathrm{c}}$ \\
BG21D & $157312.77^{\mathrm{d}}$ & $27191.38^{\mathrm{c}}$ & $90.54^{\mathrm{c}}$ \\
\hline
\end{tabular}

FGB: fresh garlic; BG7D: black garlic fermented for 7 days; BG14D: black garlic fermented for 14 days; BG21D: black garlic fermented for 21 days. Different superscript letters in the same column indicate significantly different means among samples according to Duncan test at $\mathrm{P}<0.05$

\subsection{Functional properties of black garlic}

It seems logical to state that an increase in polyphenol and flavonoid content in black garlic is due to antioxidant properties in this product (Toledano-Medina et al., 2016). Total flavonoids and polyphenols of black garlic are shown in Table 2. There were a significantly increasing total flavonoid and total polyphenol of black garlic from 7 days to 21 days fermentation process in a water bath. The total flavonoid of BG14D (black garlic fermented for 14 days) and BG21D was significantly higher than fresh garlic. Meanwhile, the total polyphenols of BG7D, BG14D, and BG21D were significantly higher than fresh garlic. These results indicate that the time period of fermentation has an important role in the increased total flavonoids and polyphenols of black garlic in addition to temperature and $\mathrm{RH}$ condition. These results are consistent with those obtained by Kim et al. (2012), who reported that total flavonoids and polyphenol in garlic might be increased by the heating process. In this study, the total flavonoid of black garlic increased up to 11.5-fold compared with fresh garlic, whereas the total polyphenol of black garlic increased to just 1.7-fold compared with fresh garlic. These results were different from the study by Kim et al. (2013), the total flavonoid and polyphenol of black garlic were increased about 1.5 -fold and 10 -fold compared with fresh garlic. Moreover, total flavonoids and polyphenols were optimum at 21 days of fermentation. The study from Choi et al. (2014) reported that total flavonoid and polyphenol of black garlic with heating over 21 days (28 and 35 days) obtained less optimum results compared with 21 days of heating.

Several reasons explain why the total flavonoids and polyphenols increased after the fermentation process. First, the fermentation process breaks the bound form like glycosylated and esterified, thus leading to an increase in free forms. Second, it is caused by the decrease in enzymatic oxidation involving the antioxidant compounds. Third, it is caused by an increase in the levels of complex polyphenol from the later phase of the browning reaction (Kim et al., 2013).

In this research, antioxidant capacity increased along with fermentation period significantly $(\mathrm{p}<0.05)$. The result of this research is in line with research by Toledano-Medina et al. (2016) and Choi et al. (2014). BG21D had 20\% of antioxidant capacity higher than Choi et al. (2014) in the same heating period. During the heating process, allin is an unstable compound in fresh garlic converted into a stable compound such as SAC (S-allyl cysteine) which has a high antioxidant capacity (Choi et al., 2014; Toledano-Medina et al., 2016; Amagase, 2006; Corzo-Martinez et al., 2007). The concentration of SAC in black garlic was $97 \mu \mathrm{g} / \mathrm{g}$, while its increase reaches of 5 to 6 -fold compared with fresh garlic (Bae et al., 2012). In addition, SAC, the research by Lee et al. (2009) reported that an increase of antioxidant capacitywas also related to an increase of polyphenols, which were derivatives from allin. These findings were in line with this research, whereas an increase of antioxidant capacity was associated with an increase in the total polyphenol (Table 2) Antioxidant capacity of BG21D increased to 4.5 folds compared with fresh garlic.

\subsection{Volatile compounds by SPME-GCMS}

Changes of volatile compounds during the manufacturing of black garlic were shown in Table 3. Fresh garlic has several signature-sulphur containing compound as well as mentioned by Arslaner (2020), who investigated yogurt enriched by garlic paste. Some of the sulfur volatiles in fresh garlic, allyl mercaptan di-2-propenyl tetrasulfide and di(1-propenyl) sulfide, were not detected in black garlic. During the fermentation process, an increase of several sulfur compounds such as dimethyl disulfide, 2-vinyl-1,3-dithiane, allyl sulfide, diallyl trisulfide, 1,2-dithiolane, methyl 2-propenyl disulfide, 1,3,5-trithiane, and cyclooctasulfur occurred. Findings in this research were quite similar to MolinaCalle et al. (2017) and Zhong-yi et al. (2012).

Other novel compounds also formed in black garlic and their concentration did increase during the fermentation period, such as allyl alcohol, acetic acid, butanediol, benzaldehyde, and isopropyl myristate. The formation of acetic acid and its increasing concentration affect the $\mathrm{pH}$ value of black garlic. Black garlic contains richer in methyl alcohol, acetone. Benzeneacetaldehyde $(4.61 \mu \mathrm{g} / \mathrm{g})$ which were only detected in BG21D. This result was in line with Molina-Calle et al. (2017) that identified the volatile compound of 5 weeks heated garlic. Fresh odor and floral flavor which is characterized by 2-butenal detected in FG and decreased in BG7D. Its concentration was not detected along with an increase in the fermentation period. This phenomenon was in line with Kim et al. (2011) and Molina-Calle et al. (2017).

The formation of furfural started at 14 days of fermentation (BG14D) and its concentration increased above 41 times higher at the end of the fermentation process. Furfural was formed as a consequence of the Maillard reaction during the fermentation or heating process. This compound was a result of the degradation of pentose sugar Molina-Calle et al. (2017). The presence of furfural leads to sweet taste and has an aromatic odor that is reminiscent of almonds (McKillip et al., 2005). 
Table 3. Volatile compound during the manufacturing of black garlic.

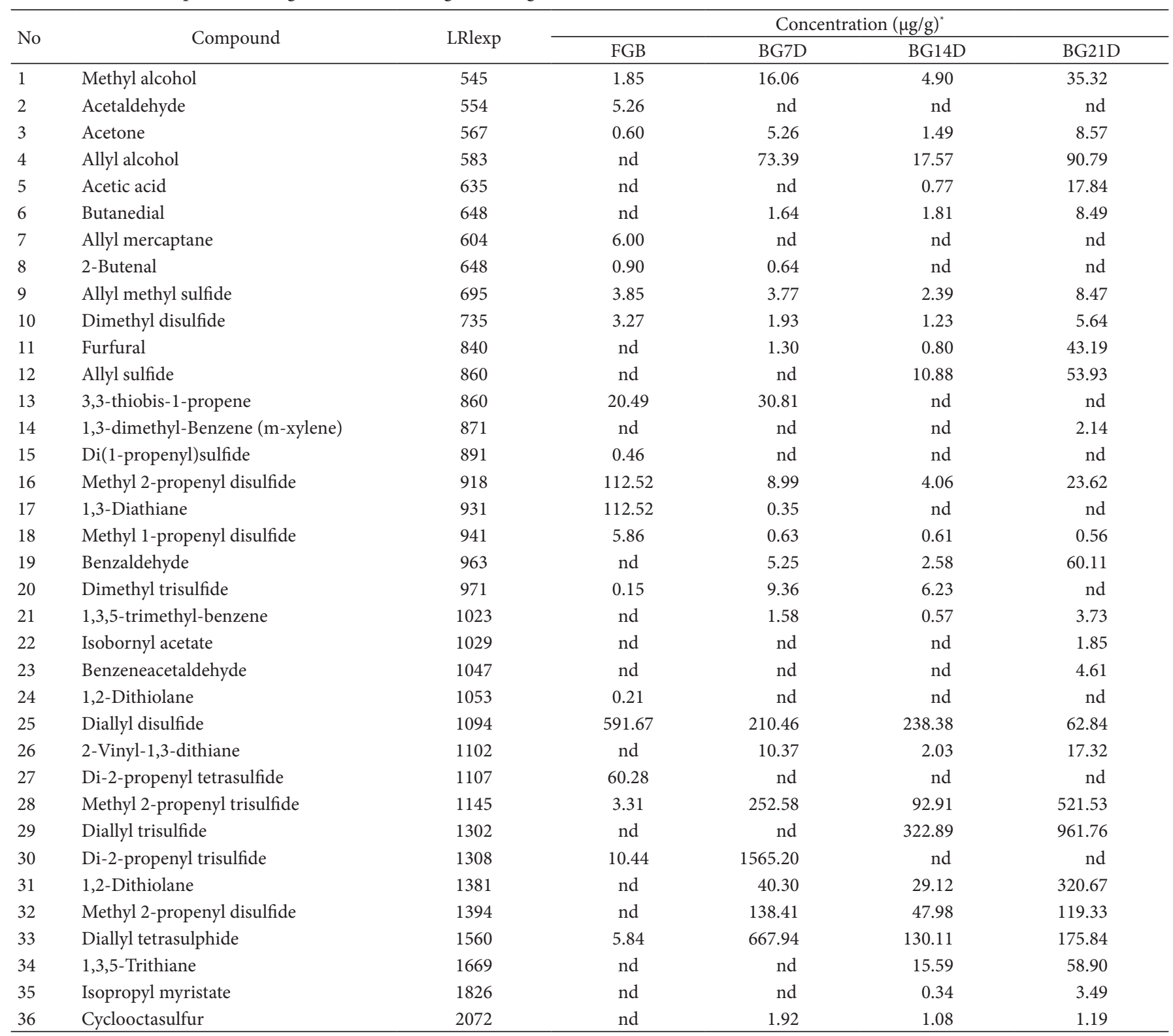

${ }^{*}$ nd: not detected. FGB: fresh garlic; BG7D: black garlic fermented for 7 days; BG14D: black garlic fermented for 14 days; BG21D: black garlic fermented for 21 days.

\section{Conclusion}

Black garlic was manufactured by fermentation in water bath at temperature of $72{ }^{\circ} \mathrm{C}$ and relative humidity close to $90 \%$. Its characterization quite differs from its fresh form. When the $\mathrm{pH}$ value decreased, its browning intensity, antioxidant capacity, total flavonoid, and total polyphenol increased. Volatile compounds in black garlic were quite different from fresh garlic. Furfural as a Maillard browning product was formed in garlic after the 7 days of the spontaneous fermentation process.

\section{Acknowledgements}

All author contributed equally to this research. This research was funded by the Ministry of Research, Technology and Higher Education of the Republic of Indonesia (INSINAS 2018). The authors thank the Research Center for Biotechnology, Indonesian Institute of Sciences for the facilities to conduct this research.

\section{References}

Amagase, H. (2006). Clarifying the real bioactive constituents of garlic. The Journal of Nutrition, 131(3, Suppl.), 955-962. http://dx.doi. org/10.1093/jn/131.3.955S. PMid:16484550.

Arslaner A. (2020). The effects of adding garlic (Allium sativum L.) on the volatile composition and quality properties of yogurt. Food Sci Technol. Ahead of Print, 1-10. http://dx.doi.org/10.1590/fst.31019.

Bae, S. E., Cho, S. Y., Won, Y. D., Lee, S. H., \& Park, H. J. (2012). A comparative study of the different analytical methods for analysis of S-allyl cysteine in black garlic by HPLC. Lebensmittel-Wissenschaft + Technologie, 46(2), 532-535. http://dx.doi.org/10.1016/j.lwt.2011.11.013. 
Bae, S. E., Cho, S. Y., Won, Y. K., Lee, S. H., \& Park, H. J. (2014). Changes in S-allyl cysteine contents and physicochemical properties of black garlic during heat treatment. Lebensmittel-Wissenschaft + Technologie, 55(1), 397-802. http://dx.doi.org/10.1016/j.lwt.2013.05.006.

Banerjee, S. K., Mukherjee, P. K., \& Maulik, S. K. (2013). Garlic as an antioxidant: the good, the bad and the ugly. Phytotherapy Research, 17(2), 97-106. http://dx.doi.org/10.1002/ptr.1281. PMid:12601669.

Billaud, C., Maraschin, C., \& Nicolas, J. (2004). Inhibition of polyphenol oxidase from apple by Maillard reaction products prepared from glucose or fructose with L-cysteine under various conditions of $\mathrm{pH}$ and temperature. Lebensmittel-Wissenschaft + Technologie, 37(1), 69-78. http://dx.doi.org/10.1016/S0023-6438(03)00136-1.

Chang, C. C., Yang, M. H., Wen, H. M., \& Chem, J. C. (2002). Estimation of total flavonoid content in propolis by two complementary colorimetric method. Yao Wu Shi Pin Fen Xi, 10(3), 178-182.

Choi, S., Cha, H. S., \& Lee, Y. S. (2014). Physicochemical and antioxidant properties of black garlic. Molecules (Basel, Switzerland), 19(10), 16811-16823. http://dx.doi.org/10.3390/molecules191016811. PMid:25335109.

Chu, Q. J., Lee, D. T. W., Tsao, S. W., Wang, X. H., \& Wong, Y. C. (2007). S-allylcyesteine, a water-soluble garlic derivative, suppresses the growth of a human androgen independent prostate cancer xenograft, CWR22R, under in vivo conditions. BJU International, 99(4), 925-932. http://dx.doi.org/10.1111/j.1464-410X.2006.06639.x. PMid:17155983.

Corzo-Martinez, M., Corso, N., \& Villamiel, M. (2007). Biological properties of onions and garlic. Trends in Food Science \& Technology, 18(12), 609-625. http://dx.doi.org/10.1016/j.tifs.2007.07.011.

Kang, M. J., Lee, S. J., Shin, J. H., Kang, S. K., Kim, J. G., \& Sung, N. J. (2008). Effect of garlic with different processing on lipid metabolism in $1 \%$ cholesterol fed rats. J Korean Soc. Food Science \& Nutrition, 37(2), 162-169. http://dx.doi.org/10.3746/jkfn.2008.37.2.162.

Kim, J. S., Kang, O. J., \& Gweon, O. C. (2013). Comparison of phenolic acids and flavonoids in black garlic at different thermal processing steps. Journal of Functional Foods, 5(1), 80-66. http://dx.doi. org/10.1016/j.jff.2012.08.006.

Kim, N. Y., Park, M. H., Jang, E. Y., \& Lee, J. (2011). Volatile distribution in garlic (Allium sativum L.) by solid phase microextraction (SPME) with different processing conditions. Food Science and Biotechnology, 20(3), 775-782. http://dx.doi.org/10.1007/s10068-011-0108-4.

Kim, S. H., Jung, E. Y., Kang, D. H., Chang, U. J., Hong, Y. H., \& Suh, H. J. (2012). Physical stability antioxidative propertise, and photoprotective effects of functionalized formulation containing black garlic extratct. Journal of photochemistry and photobiology. B, Biology, 117, 104-110. http://dx.doi.org/10.1016/j.jphotobiol.2012.08.013. PMid:23099480.

Kimura, S., Tung, Y. C., Pan, M. H., Sun, N. W., Lai, Y. J., \& Cheng, K. C. (2017). Black garlic: a critical review of its production, bioactivity, and application. Journal of food and drug analysis, 25(1), 62-70. http://dx.doi.org/10.1016/j.jfda.2016.11.003. PMid:28911544.

Lee, E. N., Choi, Y. W., Kim, H. K., Park, J. K., Kim, H. J., Kim, M. J., \& Yoon, S. (2011). Chloroform extract of aged black garlic attenuates TNF- $\alpha$-induced ROS generation, VCAM-1 expression NF- $\kappa \mathrm{B}$ activation and adhesiveness for monocytes in human umbilical vein endothelial cells. Phytotherapy Research, 25(1), 92-100. http://dx.doi.org/10.1002/ptr.3230. PMid:20623600.

Lee, Y. M., Gweon, O. C., Seo, Y. J., Im, J., Kang, M. J., Kim, M. J., \& Kim, J. I. (2009). Antioxidant effect of garlic and aged black garlic in animal model of type 2 diabetes mellitus. Nutrition Research and Practice, 3(2), 156-161. http://dx.doi.org/10.4162/nrp.2009.3.2.156. PMid:20016716.
Liang, T., Wei, F., Lu, Y., Kodani, Y., Nakada, M., Miyakawa, T., \& Tanokura, M. (2015). Comprehensive NMR analysis of compositional changes of black garlic during thermal processing. Journal of Agricultural and Food Chemistry, 63(2), 683-69. http://dx.doi.org/10.1021/ jf504836d. PMid:25549134.

Lu, X., Li, N., Qiao, X., Qiu, Z., \& Liu, P. (2018). Effects of thermal treatment on polysaccharide degradation during black garlic processing. Lebensmittel-Wissenschaft + Technologie, 95, 223-229. http://dx.doi.org/10.1016/j.lwt.2018.04.059.

McKillip, W. J., Collin, G., Hoke, H., \& Zeitsch, K. J. (2005). Furan and Derivatives in Ullmann's Encyclopedia of Industrial Chemistry (pp. 5-7). Weinheim: Wiley-VCH Verlag GmbH \& Co KgaA

Molina-Calle, M., Priego-Capote, F., \& de Castro, M. D. L. (2017). Headspace-GCMS volatile profile of black garlic vs fresh garlic: Evolution along fermentation and behavior under heating. Lebensmittel-Wissenschaft + Technologie, 80, 98-105. http://dx.doi. org/10.1016/j.lwt.2017.02.010.

Muanda, F., Kone, D., Dicko, A., Soulimani, R., \& Younos, C. (2011). Phytochemical composition and antioxidant capacity of three malian medicinal plant parts. Evidence-Based Complementary and Alternative Medicine, 2011, 1-8. http://dx.doi.org/10.1093/ecam/ nep109. PMid:19736222.

Ngan N, Giang M, Tu N. (2017). Biological activities of black garlic fermented with Lactobacillus plantarum PN05 and some kinds of black garlic presenting inside Vietnam. Indian Journal of Pharmaceutical Education and Research, 51(4), 672-678.

Qiu, Z., Li, N., Lu, X., Zheng, Z., Zhang, M., \& Qiao, X. (2018). Characterisation of microbial community structure and metabolic potential using Illumina MiSeq platform during the black garlic processing. Food Research International, 106, 428-438. http://dx.doi.org/10.1016/j.foodres.2017.12.081. PMid:29579944.

Sato, E., Kohno, M., Hamano, H., \& Niwano, Y. (2006). Increased antioxidative potency of garlic by spontaneous short-term fermentation. Plant Foods for Human Nutrition, 61(4), 157-160. http://dx.doi. org/10.1007/s11130-006-0017-5. PMid:17075725.

Setiyoningrum, F., Priadi, G., Herlina, N., Solikhin, A., \& Lisani, N. (2018). Functional properties of Saccharomyces kluyveri Y97fermented solo black garlic. Asian Journal Agriculture, 2(2), 48-51. http://dx.doi.org/10.13057/asianjagric/g020203.

Sultan, M. T., Buttxs, M. S., Qayyum, M. M. N., \& Suleria, H. A. R. (2014). Immunity: plants as effective mediators. Critical Reviews in Food Science and Nutrition, 54(10), 1298-12308. http://dx.doi.org/ 10.1080/10408398.2011.633249. PMid:24564587.

Tanamai, J., Veeramanomai, S., \& Indrakosas, N. (2017). The efficacy of cholesterol-lowering action and side effects of garlic enteric coated tablets in man. Journal of the Medical Association of Thailand, 87(10), 1156-1161. PMid:15560690.

Toledano-Medina, M. A., Pérez-Aparicio, J., Moreno-Rojas, R., \& Merinas-Amo, T (2016). Evolution of some physicochemical and antioxidant properties of black garlic whole bulbs and peeled cloves. Food Chemistry, 166, 135-139. http://dx.doi.org/10.1016/j. foodchem.2015.11.128. PMid:26775954.

Wang, W., \& Sun, Y. (2017). In vitro and in vivo antioxidant activities of polyphenol extracted from black garlic. Food Sci Technol., 37(4), 681-685. http://dx.doi.org/10.1590/1678-457x.30816.

Wang, X., Jiao, F., Wang, Q. W., Wang, J., Yang, K., Hu, R. R., Liu, H. C., Wang, H. Y., \& Wang, Y. S. (2012). Aged black garlic extract induces inhibition of gastric cancer cell growth in vitro and in vivo. Molecular Medicine Reports, 5(1), 66-72. http://dx.doi.org/10.3892/ mmr.2011.588. PMid:21922142. 
Yuan, H., Sun, L., Chen, M., \& Wang, J. (2016). The comparison of the contents of sugar compounds in fresh and black garlic. Journal of Food Science, 81(7), 1662-1668. http://dx.doi.org/10.1111/17503841.13365. PMid:27300762.

Yuan, H., Sun, L., Chen, M., \& Wang, J. (2018). An analysis of the changes on intermediate products during the thermal processing of black garlic. Food Chemistry, 239, 56-61. http://dx.doi.org/10.1016/j. foodchem.2017.06.079. PMid:28873605.

Zhang, X., Li, N., Lu, X., Liu, P., \& Qiao, X. (2016). Effect of temperature on the quality of black garlic. Journal of the Science of Food and
Agriculture, 96(7), 2366-2372. http://dx.doi.org/10.1002/jsfa.7351. PMid:26212875.

Zhang, Z., Lei, M., Liu, R., Gao, Y., Xu, M., \& Zhang, M. (2015). Evaluation of allin, saccharide content and antioxidant activities of black garlic during thermal processing. Journal of Food Biochemistry, 39(1), 39-47. http://dx.doi.org/10.1111/jfbc.12102.

Zhong-yi, Z., Xiao-juan, Y., Jun-song, Z., \& Wen-ye, Z. (2012). Identification of volatile compounds in fermented black garlic by GC-MC. China Condiment, 7(74), 1-6. Retrieved from: http:// en.cnki.com.cn/Article en/CJFDTOTAL-ZGTW201207021.htm 